\title{
The ethanol extracts of sporoderm-broken spores of Ganoderma lucidum inhibit colorectal cancer in vitro and in vivo
}

\author{
KANG LI, KUN NA, TINGTING SANG, KAIKAI WU, YING WANG and XINGYA WANG \\ College of Pharmaceutical Sciences, Zhejiang Chinese Medical University, Hangzhou, Zhejiang 310053, P.R. China
}

Received March 24, 2017; Accepted August 17, 2017

DOI: $10.3892 /$ or.2017.6010

\begin{abstract}
The medicinal mushroom Ganoderma lucidum (G. lucidum) has been reported to possess a variety of pharmacological activities including anticancer effects. However, the anti-colorectal cancer effects and the potential molecular mechanisms of the ethanol extracts of sporoderm-broken spores of G. lucidum (BSGLEE), which mainly contains triterpenoids, have not been reported. The aim of the present study was to investigate the anticancer effects and molecular mechanisms exerted by BSGLEE on colorectal cancer in vitro and in vivo. MTT assay revealed that BSGLEE at 1.6 to $10 \mathrm{mg} / \mathrm{ml}$ significantly inhibited HCT116 cell proliferation in a dose- and time-dependent manner. Flow cytometric analysis demonstrated that BSGLEE induces apoptosis and cell cycle arrest at G0/G1 phase, which are associated with deregulation of the expression of key genes and proteins (p21, p16, cyclin D1, Bcl-2, bax, NAG-1, PARP and caspase-3) that regulate apoptosis and cell cycle cascades. Moreover, BSGLEE significantly inhibited HCT116 cell migration via downregulating MMP-1, MMP-2 and upregulating E-cadherin expression at mRNA levels. Oral gavage of 75 and $150 \mathrm{mg} / \mathrm{kg}$ BSGLEE significantly inhibited HCT116 xenograft tumor growth in nude mice, which was accompanied by suppressed Ki-67 staining as determined by immunochemistry. Collectively, we found that BSGLEE effectively inhibits colorectal cancer carcinogenesis through induction of apoptosis, inhibition of migration and promotion of cell cycle arrest. Our results suggest that triterpenoids of sporoderm-broken spores of G. lucidum ethanol extracts may serve as a promising anticancer agent for colorectal cancer chemoprevention and therapy.
\end{abstract}

Correspondence to: Dr Xingya Wang, College of Pharmaceutical Sciences, Zhejiang Chinese Medical University, 548 Binwen Road, Hangzhou, Zhejiang 310053, P.R. China

E-mail: xywang@zcmu.edu.cn

Abbreviations: G. lucidum, Ganoderma lucidum; BSGL, powder of sporoderm-broken spores of G. lucidum; pBSGLEE, ethanol extracts of sporoderm-broken spores of G. lucidum; NAG-1, non-steroidal anti-inflammatory drug-activated gene-1

Key words: Ganoderma lucidum, colon cancer, apoptosis, triterpenoids

\section{Introduction}

Colorectal cancer is one of the malignant tumors that affects human health and life worldwide, and it is the third most common cancer and the fourth cause of cancer-related mortality in western countries (1). At present, other than surgery, chemotherapy and radiotherapy are the two dominant strategies for treating colorectal cancer. Unfortunately, these strategies are associated with undesirable side-effects including nausea, diarrhea, poor quality of life and others. Thus, the development of novel anticancer agents against colorectal cancer from nature is urgently needed. In particular, those with a history of medicinal use from the rich traditional Chinese medicine (TCM) resources are of great interest.

The medicinal mushroom G. lucidum, also called Reshi in Japan and Lingzhi in China, has been consumed for thousands of years in East Asia to promote longevity and improve overall health (2). G. lucidum has been reported to possess anti-inflammatory activities $(3,4)$, antitumor activities $(5,6)$, alleviating hepatotoxicity activities $(7,8)$, analgesic effects $(9,10)$ and anti-HIV-1 activities (11). Currently, over 300 active compounds have been isolated from G. lucidum fruiting bodies, mycelia and spores (12). The bio-active substances of G. lucidum include polysaccharides, triterpenoids, amino acids, peptides, fatty acids, oligosaccharides and trace elements, especially over 150 triterpenoids have been isolated from G. lucidum (13). Among these active components, triterpenoids (major active component of the ethanol extracts of $G$. lucidum) and polysaccharides (major active component of the water extracts of G. lucidum) have been extensively studied for their anticancer effects against many types of cancers. At present, a large number of studies have found that ethanol extracts of G. lucidum has a broad spectrum anticancer effects how human gastric $(14,15)$, urothelial $(16)$, ovarian (17), colon (18) and liver (19) cancers. However, it still remains unclear about the exact mechanism by which the ethanol extracts of G. lucidum exert for its anticancer effects in these cancers. In addition, most of the above studies examined triterpenoids extracted from fruiting bodies or mycelia of G. lucidum. Only few studies examined the triterpenoids extracted from the sporoderm-broken spores of G. lucidum for their anticancer effects. Min et al (20) reported that the spores contain more triterpenoids compared with other parts of G. lucidum. However, it has not been reported whether the sporoderm-broken spores of G. lucidum ethanol extracts 
(BSGLEE) could inhibit colorectal cancer carcinogenesis either in vitro or in vivo.

Therefore, in the present study we examined the anticancer effects of BSGLEE on colorectal cancer and the potential molecular mechanisms underlying these activities of BSGLEE were also explored. From in vitro and in vivo studies we demonstrate that BSGLEE is effective in inhibiting HCT116 cancer cell proliferation and tumor growth through regulating key genes and proteins involved in apoptosis, migration and cell cycle arrest.

\section{Materials and methods}

Materials. FITC Annexin V apoptosis detection kit and propidium iodide (PI)/RNase staining solution were purchased from BD Biosciences (San Diego, CA, USA). Hoechst 33342 was obtained from Invitrogen (Carlsbad, CA, USA). [3-(4, 5-dimethylthia-zol-2-yl)-2,5-diphenyltetrazolium bromide] (MTT) was obtained from HXBIO (Hangzhou, China). Polyclonal $\beta$-actin and PARP antibodies, and monoclonal pro-caspase- 3 , cleaved caspase- 3 and pro-caspase- 7 antibodies were obtained from Cell Signaling Technology (Danvers, MA, USA). RNA extraction kit was purchased from Aidlab Biotechnologies Co., Ltd. (Beijing, China). The iScript cDNA Synthesis kit and SYBR Master Mix were purchased from Bio-Rad Laboratories (Hercules, CA, USA). The bicinchoninic acid (BCA) assay kit was purchased from Pierce (Rockford, IL, USA). The Western Lightening ${ }^{\mathrm{TM}}$ Plus-ECL Enhanced chemiluminescence substrate assay kit was purchased from Perkin-Elmer (Waltham, MA, USA). Ki-67, Bax, Bcl-2 and cyclin D1 antibodies for immunohistochemistry were obtained from Wuhan Goodbio Technology Co., Ltd. (Wuhan, China). Transwell plates were purchased from Costar, Inc., (Kennebunk, ME, USA).

BSGL ethanol extract preparation. Powder of sporodermbroken spores of G. lucidum (BSGL) were purchased from Taian Zhengxin Science and Technology Co., Ltd. (Anhui, China). The tritepenoids from the powder of sporoderm-broken spores of G. lucidum were extracted by modified protocol based on ethanol extraction method described before (21). The modification was based on results of orthogonal experiments. Briefly, we adopted the following conditions: $95 \%$ of ethanol, $85^{\circ} \mathrm{C}$ of extraction temperature, $2 \mathrm{~h}$ of extraction time, ratio of material to liquid as 1:60 (g/ml) and 2 times of extraction. The extraction solution was centrifuged at $3000 \mathrm{x}$ g for $3 \mathrm{~min}$ and then the supernatant was collected. The ethanol solvent in the supernatant was removed using a vacuum evaporator. The dried extracts were weighed and stored at $-20^{\circ} \mathrm{C}$ for further analysis for subsequent experiments. BSGLEE was weighed and dissolved in dimethyl sulfoxide (DMSO) and further diluted using the corresponding cell culture medium immediately at stock solution of $10 \mathrm{mg} / \mathrm{ml}$.

Cell culture. The colon cancer cell line HCT116 was purchased from the American Type Culture Collection (ATCC; Manassas, VA, USA). HCT116 cells were maintained in Dulbecco's modified Eagle's medium (DMEM; Gibco, Gaithersburg, MD, USA) containing $10 \%$ fetal bovine serum (FBS; Gibco) and $100 \mathrm{units} / \mathrm{ml}$ penicillin (Invitrogen), $0.1 \mathrm{mg} / \mathrm{ml}$ streptomycin
(Invitrogen) and cultured at $37^{\circ} \mathrm{C}$ in a humidified atmosphere with $5 \% \mathrm{CO}_{2}$.

Morphological observation and MTT assay. In order to explore whether HCT16 cells may be killed by BSGLEE, morphological observation was conducted in the test. HCT116 cells were seed in 6 -well plate at $2 \times 10^{5}$ cells/well and incubated at $37^{\circ} \mathrm{C}$ in the presence of $5 \% \mathrm{CO}_{2}$. After $24-\mathrm{h}$ incubation when cells reached $\sim 50 \%$ confluence, cells were treated with different concentrations of BSGLEE $(0,0.64$, 1.6, 4.0 and $10.0 \mathrm{mg} / \mathrm{ml}$ ) for $48 \mathrm{~h}$. Phase contrast images of the conditioned cells were captured by Motic phase contrast microscope equipped with a digital camera (Motic, Xiamen, China) to obtain the effects of different concentrations of BSGLEE on the number and morphology of HCT116 cells. In addition, cell viability was detected by MTT assay. Briefly, HCT116 cells were seeded in 96-well plates at $1 \times 10^{4}$ cells/well. Cells were treated with various concentrations of BSGLEE $(0,0.64,1.6,4$ and $10 \mathrm{mg} / \mathrm{ml})$ in DMEM for 24,48 and $72 \mathrm{~h}$. Next, $20 \mu \mathrm{l}$ of MTT solution $(5 \mathrm{mg} / \mathrm{ml})$ was added to each well followed by incubation for $4 \mathrm{~h}$ at $37^{\circ} \mathrm{C}$. Then the medium was discarded and $200 \mu 1 \mathrm{DMSO}$ was added to dissolve the formazan crystals. Viable cells were detected by measuring absorbance at $490 \mathrm{~nm}$ using a microplate reader (BioTek Instruments, Inc., Winooski, VT, USA). As BSGLEE at $0.64 \mathrm{mg} / \mathrm{ml}$ failed to kill HCT116 as significantly as other concentrations, $0.64 \mathrm{mg} / \mathrm{ml}$ was eliminated in the subsequent experiments.

Flow cytometric analysis of apoptosis and cell cycle arrest. The distribution of numbers of apoptotic cells and cells in different cell cycle phases upon BSGLEE $(0,1.6,4$ and $10 \mathrm{mg} / \mathrm{ml}$ ) treatments in HCT116 cells were detected by flow cytometry. Briefly, cells ( $2 \times 10^{5}$ cells/well $)$ were seeded in 6-well plates. For apoptosis analysis, after 24 -h incubation while cells reached $~ 50 \%$ confluence, HCT116 cells were exposed to BSGLEE for $36 \mathrm{~h}$. The treated cells were collected and washed twice with cold phosphate-buffered saline (PBS). At least $1 \times 10^{5}$ cells were resuspended in $100 \mu 11 \mathrm{X}$ binding buffer containing $5 \mu \mathrm{l}$ of FITC Annexin $\mathrm{V}$ and $5 \mu \mathrm{l}$ propidium iodide (PI). The cells were gently vortexed, and then incubated for $15 \mathrm{~min}$ at RT in the dark and $400 \mu \mathrm{l}$ of $1 \mathrm{X}$ binding buffer was added to each tube. The cell apoptosis rates were analyzed by Guava easyCyte HT flow cytometry system (Merck KGaA, Darmstadt, Germany). For cell cycle analysis, after 24-h incubation ( $\sim 50 \%$ confluence), the cells were treated with BSGLEE $(0,1.6,4$ and $10 \mathrm{mg} / \mathrm{ml})$ for $48 \mathrm{~h}$. According to manufacturer's protocol (BD Biosciences), cells were harvested and fixed in $70 \%$ ethanol and then stored at $-20^{\circ} \mathrm{C}$ for $2 \mathrm{~h}$ minimum. The cells were washed twice to remove the ethanol residue and stained in $0.5 \mathrm{ml}$ of PI/RNase staining buffer in the dark at room temperature (RT) for $30 \mathrm{~min}$. The cell cycle was analyzed using the same flow cytometer as stated above. The DNA content in the G0/G1, S and G2/M phase was analyzed by ModFit 3.2 LT software (Verity Software House, Topsham, ME, USA).

Hoechst staining. DNA staining was performed using the Hoechst 33342 staining to confirm the alterations of nuclei morphology in HCT116 cells after BSGLEE treatment. 
Table I. Primer sequences used in qRT-PCR.

\begin{tabular}{lll}
\hline Primer & \multicolumn{1}{c}{ Forward primer } & \multicolumn{1}{c}{ Reverse primer } \\
\hline c-Met & TTCTGACCGAGGGAATCATCA & CCTTCACTTCGCAGGCAGAT \\
Cyclin D1 & GTGGCCTCTAAGATGAAGGAGA & GGAAGTGTTCAATGAAATCGTG \\
CDK1 & CAGCCTTGGGACAATAATGC & TTGCACGTTGAGTTTGGTA \\
CDK2 & TAGCGCGGATCTACCATACC & CATGGCTACCACTTGACCTGT \\
CDK4 & CAGGATGTGACCAAGCCAGT & TGAGTCCAAATAGCCCAAGG \\
p16 & CTGGACACTGAGAGGGCAAT & TGGGAAGGAGAAGGAGAAGC \\
p21 & ACCAGAGGCAGTAACCATGC & TGATCTAAGTTTCCCGAGGTT \\
Bcl-2 & TTAGCAGCGGAACAAGGAGT & CGTTAGTGCCAGGAAAGACA \\
NAG-1 & AAGAGCAGACGGATGGAAAAAGG & GGGCAAAGAAATGCAAGTGAATG \\
Bax & ACCTGCACAGCCATGCCCGGGCA & CAGTGGAAGGACCAGGACTGCTC \\
Fra-1 & CCGATGGCAACTTCAACTGGG & GTCAGCACTCCCGCCACAAAG \\
E-cad & CAGCTCATCGCAAGAGTAGCA & CAAAGCGAGGAGGGTTGGA \\
MMP-1 & GGTCTCTCTCACCACCTCCA & CCTCGGACACTTCCACTCTC \\
MMP-2 & GGGAGATCATCGGGACAACTC & GGGCCTGGTTGAAAAGCAT \\
Vimentin & AGTTTCCATTCCGCTTCCAG & CGGTCGTAGTCCTCAGTGGT \\
$\beta-$ actin & AGAGAACTTTGCCGTTGAAGC & ACGAAGGTGACGAGCCATT \\
\hline & CTGGAACGGTGAAGGTGACA & AAGGAACTTCCTTGAACAATGCA
\end{tabular}

Briefly, HCT116 cells were treated with BSGLEE $(0,1.6,4$ and $10 \mathrm{mg} / \mathrm{ml}$ ) for $36 \mathrm{~h}$ and then stained with Hoechst 33342 $(10 \mu \mathrm{g} / \mathrm{ml})$ for $15 \mathrm{~min}$ at RT in the dark. The nuclear morphology of HCT116 cells was observed using fluorescence microscope at a magnification of 200-fold (Nikon, Tokyo, Japan) after being washed with PBS. Image from 5 randomly selected microscopic fields were captured and only one representative picture was presented.

Cell migration analysis. Cell migration ability was evaluated by wound healing assay as previously described (22). Briefly, HCT116 cells were seeded in 6-well plates $\left(2.0 \times 10^{5}\right.$ cells/well), and when cells reached $\sim 90 \%$ confluence, wound was created by scratching the cell monolayer using a pipette tip and then washed with PBS for removal of cell debris. Cells were exposed to BSGLEE and allowed to migrate into the wound area for 12 and $24 \mathrm{~h}$. Images of the wound area were captured using the inverted microscope (Nikon, Tokyo, Japan).

Transwell migration assay. Cell migration ability was evaluated by 24 -well Transwell chamber according to the manufacturer's instruction. Briefly, HCT116 cells were seeded in 6-well plates, and when cells reached $\sim 90 \%$ confluence, the cells were treated with different concentrations of BSGLEE $(0,1.6,4.0$ and $10.0 \mathrm{mg} / \mathrm{ml})$ for $24 \mathrm{~h}$. Then, cells were trypsinized and counted. Next, $2.0 \times 10^{5}$ HCT 116 cells in $100 \mu \mathrm{l}$ of serum-free medium were placed into top chambers of Transwell plate, and $600 \mu 1$ medium with $20 \%$ FBS was added in the lower chambers. The plate was incubated in 5\% $\mathrm{CO}_{2}$ for additional $24 \mathrm{~h}$ at $37^{\circ} \mathrm{C}$. Cells penetrating through the porous membrane were detected by hematoxylin and eosin staining (H\&E), and then observed with light microscope (Leica Microsystems, Wetzlar, Germany). The number of cells stained were counted in five random fields of each chamber.
Western blot analysis. After treatment with BSGLEE for $48 \mathrm{~h}$, cells were washed twice with PBS and fully lysed with icecold RIPA buffer (Sigma-Aldrich, St. Louis, MO, USA). Then cell lysates were centrifuged at $13,000 \mathrm{rpm}$ for $10 \mathrm{~min}$ at $4^{\circ} \mathrm{C}$. Supernatants were collected and concentration of total protein was quantified by BCA assay. Protein samples ( $40 \mu \mathrm{g} / \mathrm{lane})$ were separated by $10-12 \%$ SDS-PAGE gel and then transferred to polyvinylidene fluoride membranes (PVDF) (Merck Millipore, Darmstadt, Germany) using a transfer system (Bio-Rad Laboratories, $100 \mathrm{v}, 120 \mathrm{~min}$ ). After blocking with $5 \%$ skim milk in TBST for $1 \mathrm{~h}$ at RT, the membranes were incubated overnight at $4^{\circ} \mathrm{C}$ in the primary antibody solution against pro-caspase-3, cleaved caspase- 3 , pro-caspase- 7 and PARP antibodies according to the manufacturer's instruction. Membranes were washed 3 times with TBST for $10 \mathrm{~min}$ and incubated in the HRP-conjugated secondary antibody solution (Cell Signaling Technology, Inc., Beverly, MA, USA) for $1 \mathrm{~h}$ at room temperature. The signals were detected using ECL chemiluminescence reagent (Perkin-Elmer) and $\beta$-actin was used as loading control.

Quantitative real-time PCR ( $q R T$ - $P C R)$. Total RNA was isolated using RNA kit from Aidlab following instruction. The concentration and purity of total RNA was determined by NanoDrop 2000 (Thermo Fisher Scientific, Waltham, MA, USA). cDNA was synthesized with iScript cDNA Synthesis Kit (Bio-Rad Laboratories). PCR amplification was performed using a SYBR Master Mix (Bio-Rad Laboratories) on CFX-96 real-time PCR system (Bio-Rad Laboratories). $\beta$-actin was used as an internal control. Fold changes relative to the control were calculated according to the $2^{-\Delta \Delta \mathrm{Ct}}$ method. The primer sequences are listed in detail in Table I.

In vivo xenograft nude mouse study. To determine the inhibitory effects of BSGLEE on occurrence and development of 
colon tumor in vivo, in total 44, 5-week-old male BALB/c nude mice were fed in specific pathogen free (SPF) environment. All experimental procedures were conducted following the Guide for the Use and Care of Laboratory Animals of the National Institutes of Health. This study was approved by the Committee on the Ethics of Animal Experiments of Zhejiang Chinese Medical University (Permit no: SYXK 2012-0002). HCT116 cells $\left(5 \times 10^{6}\right)$ suspended in $200 \mu 1$ PBS were transplanted into the right flank of the nude mice. The nude mice were randomly divided into normal group (no HCT116 cell injection, $n=8$, PBS), model group ( $\mathrm{n}=12$, PBS), low-dose group $(\mathrm{n}=12,75 \mathrm{mg} / \mathrm{kg}$ BSGLEE) and high-dose group $(\mathrm{n}=12$, $150 \mathrm{mg} / \mathrm{kg}$ BSGLEE) on the day of cell transplantation. The day after HCT116 injection, the mice were treated with BSGLEE once a day by oral gavage. Palpable tumor was examined every day until no more tumors formed in each group. The mice were weighed and tumor sizes were measured using a digital vernier caliper $(0.01 \mathrm{~mm})$ twice a week. After 5 weeks of treatment, the mice were sacrificed and dissected. Tumor tissues were weighed and fixed in $4 \%$ formalin for $24 \mathrm{~h}$ and then processed and embedded in paraffin. Tumor volume was calculated as follows: Tumor volume $=($ length $\mathrm{x}$ width $\mathrm{x}$ width $) / 2$.

Immunohistochemistry and $H \& E$ staining. Paraffin-embedded tissue blocks were cut into serial sections $(4 \mu \mathrm{m})$ and the expression of Ki-67, Bax, Bcl-2 and cyclin D1 were determined by immunohistochemistry staining. Briefly, the sections were deparaffinized using citric acid buffer ( $\mathrm{pH}$ 6.0), and then the slides were treated with $3 \%$ hydrogen peroxide to block endogenous peroxidase activity before incubation with Ki-67 (GB13030-2, 1:1,000 diluted in 1\% BSA), Bcl-2 (GB12008-1, 1:400), Bax (GB11007, 1:300) and cyclin D1 (GB GB13079, 1:200) primary antibodies. The slides were then incubated with $5 \mu \mathrm{g} / \mathrm{ml}$ biotinylated anti-goat IgG secondary antibody (Dako, Carpinteria, CA, USA) for $30 \mathrm{~min}$ at room temperature. After washing, slides were stained with 3,3'-diaminobenzidin (DAB; Dako), and then counterstained with hematoxylin, dehydrated and mounted with a coverslip. For hematoxylin and eosin (H\&E) staining, sections were deparaffinized with xylene for $10 \mathrm{~min}$ and then rehydrated. The sections were stained with hematoxylin for $10 \mathrm{~min}$ and then stained with eosin for $1 \mathrm{~min}$. The sections were dehydrated and mounted. All images were captured using an inverted fluorescence microscope (Nikon, Tokyo, Japan).

Statistical analysis. The SPSS 17.0 software (SPSS, Inc., Chicago, IL, USA) was used for statistical analysis. The data are presented as mean \pm standard deviation or standard error. Comparisons among the different groups were performed by the one-way analysis of variance (ANOVA). A probability value of $\mathrm{P}<0.05$ was considered significant.

\section{Results}

BSGLEE inhibits cell proliferation in HCT116 cells. MTT assay and microscope observation were used to examine anti-proliferation effects of BSGLEE $(0-10 \mathrm{mg} / \mathrm{ml})$ in HCT116 cells. As shown in Fig. 1A, the number of HCT116 cells with BSGLEE incubation for $48 \mathrm{~h}$ decreased significantly compared to control cells, which is inversely correlated with the dose
A $\operatorname{BSGLEE}(\mathrm{mg} / \mathrm{ml})$

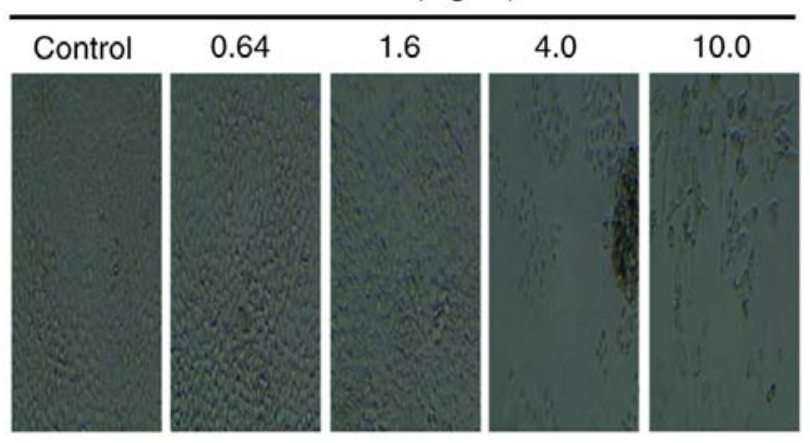

B

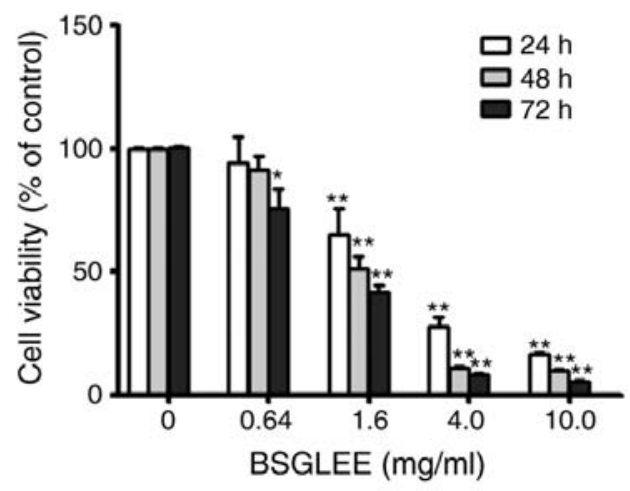

Figure 1. The cytotoxic effect of BSGLEE $(0-10 \mathrm{mg} / \mathrm{ml})$ on HCT116 cells (A) Microscopic observation of HCT116 cells treated with BSGLEE for $48 \mathrm{~h}$. (B) Cell viability was examined by MTT assay. Data shown are the means of 3 independent experiments as mean \pm SD. Each study was carried out in triplicate, ${ }^{*} \mathrm{P}<0.05,{ }^{* *} \mathrm{P}<0.01$.

of BSGLEE. MTT assay further confirmed that within the concentration of BSGLEE range from 1.6 to $10 \mathrm{mg} / \mathrm{ml}$, the proliferation of HCT116 cells was significantly inhibited with the increase of the dosage of BSGLEE $(\mathrm{P}<0.01$; Fig. 1B). We found that the inhibitory effect of BSGLEE on HCT116 cell proliferation is also time-dependent. As shown in Fig. 1B, at each dose of BSGLEE, cell proliferation decreased significantly with prolonged treatment from 24 to $72 \mathrm{~h}(\mathrm{P}<0.01)$. To further determine the relationship between time and efficacy of BSGLEE activity, the $\mathrm{IC}_{50}$ values of BSGLEE in HCT116 cells were calculated by the CompuSyn software to be 2.79 , 1.77 and $1.29 \mathrm{mg} / \mathrm{ml}$ at 24,48 and $72 \mathrm{~h}$, respectively (data not shown). Taken together, these results suggest that BSGLEE could significantly inhibit HCT116 cancer cell proliferation at a time- and dose-dependent manner. As the BSGLEE at $0.64 \mathrm{mg} / \mathrm{ml}$ did not show significant inhibition of cell viability as determined by MTT assay, we eliminated this concentration in subsequent experiments.

BSGLEE induces G0/G1 cell cycle arrest in HCT116 cells. We next examined the cell cycle distribution of HCT116 cells treated with different concentrations of BSGLEE at $48 \mathrm{~h}$. Our result indicated that BSGLEE treatment caused a significant accumulation of cell population in the G0/G1 phase compared with untreated cells (Fig. $2 \mathrm{~A}$ and $\mathrm{B} ; \mathrm{P}<0.05$ ). In particular, the highest concentration of BSGLEE $(10 \mathrm{mg} / \mathrm{ml})$ increased up to $28 \%$ more cell accumulated in G0/G1 phase (Fig. 2A), suggesting a G0/G1 phase arrest by BSGLEE in 

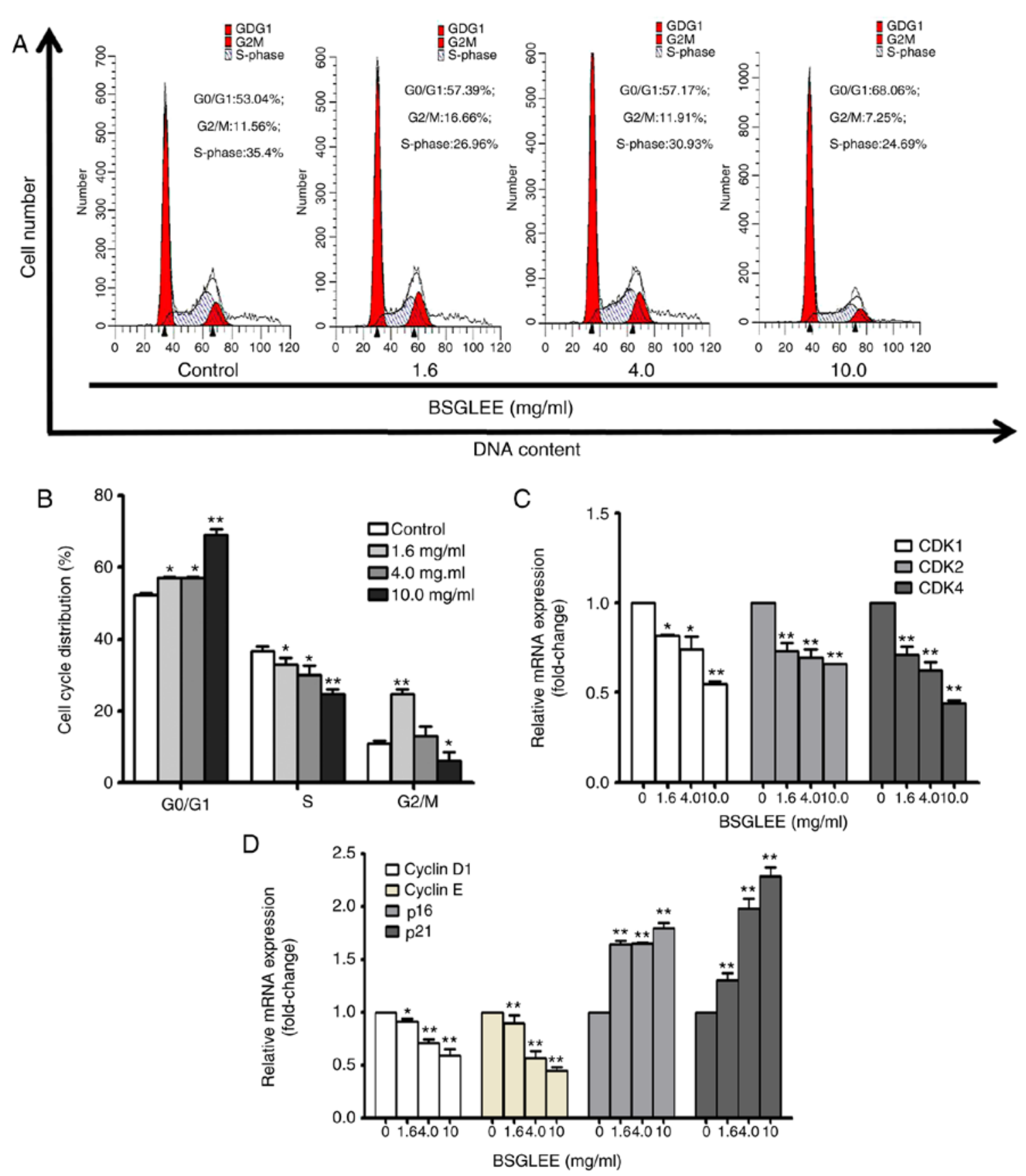

Figure 2. Effects of BSGLEE on cell cycle progression in HCT116 cells. (A) Flow cytometric analysis of cell cycle in HCT116 cells upon exposure to BSGLEE at $0,1.6,4.0$ and $10.0 \mathrm{mg} / \mathrm{ml}$ for $48 \mathrm{~h}$. Figure shows a representative image from three independent experiments. (B) Quantified histograms of the effect of BSGLEE on HCT116 cell cycle distribution. (C and D) The expression of the cell cycle-related genes as determined by qRT-PCR in HCT116 cells. Data are presented as mean $\pm \mathrm{SD}$ of three independent experiments, ${ }^{*} \mathrm{P}<0.05,{ }^{* *} \mathrm{P}<0.01$.

HCT116 cells. Furthermore, BSGLEE also significantly reduced cell accumulation in S phase (Fig. 2A and B). To further examine the underlying mechanism of the anticancer effects of BSGLEE, we conducted qRT-PCR assay to detect the expression of key genes that regulate cell cycle progression in HCT116 cells. Our results showed that the relative mRNA expression levels of CDK1, CDK2, CDK4, cyclin D1 and cyclin $\mathrm{E}$ were downregulated, while the relative mRNA expression levels of p16 and p21 were upregulated upon BSGLEE treatments in a dose-dependent manner $(\mathrm{P}<0.05$; Fig. 2C and D). Collectively, these data indicate that BSGLEE could significantly inhibit HCT116 cell proliferation through inducing cell cycle arrest at G0/G1 phase which is associated with regulating key genes that modulate cell cycle progression.

BSGLEE induces apoptosis in HCT16 cells. It is well recognized that one important type of cell death caused by anticancer agents is due to apoptosis. Thus, we examined whether BSGLEE could induce apoptosis in HCT116 cells. As shown in Fig. 3A, we found that HCT116 cells exposed to BSGLEE at $36 \mathrm{~h}$ exhibited morphological features of apoptotic cells as observed with an increased percentage of cells with brighter nuclear and fragments that were determined by Hoechst staining assay (Fig. 3A). Next, the distribution of apoptotic cells was quantified by flow cytometry. As shown in 

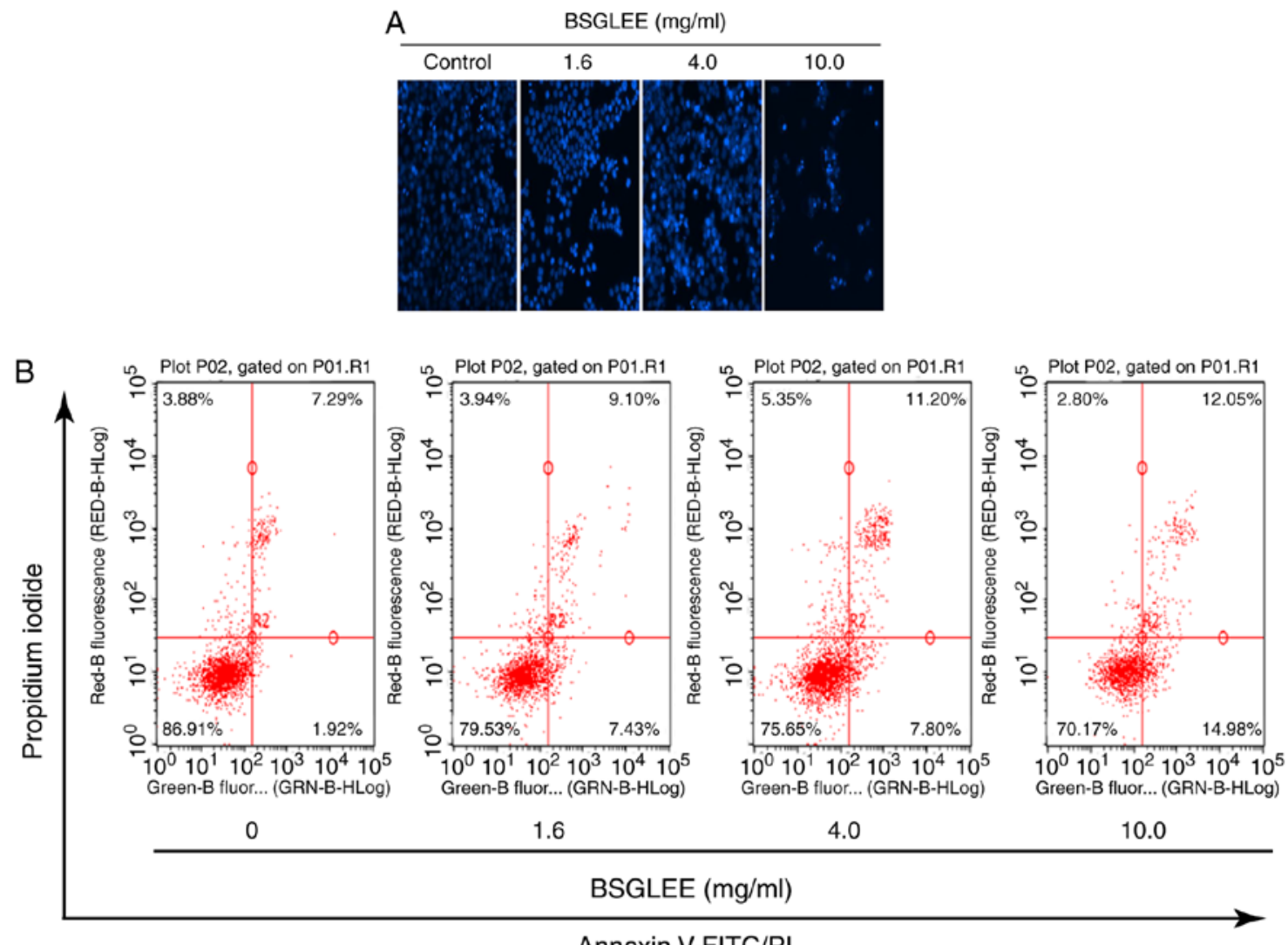

Annexin V-FITC/PI
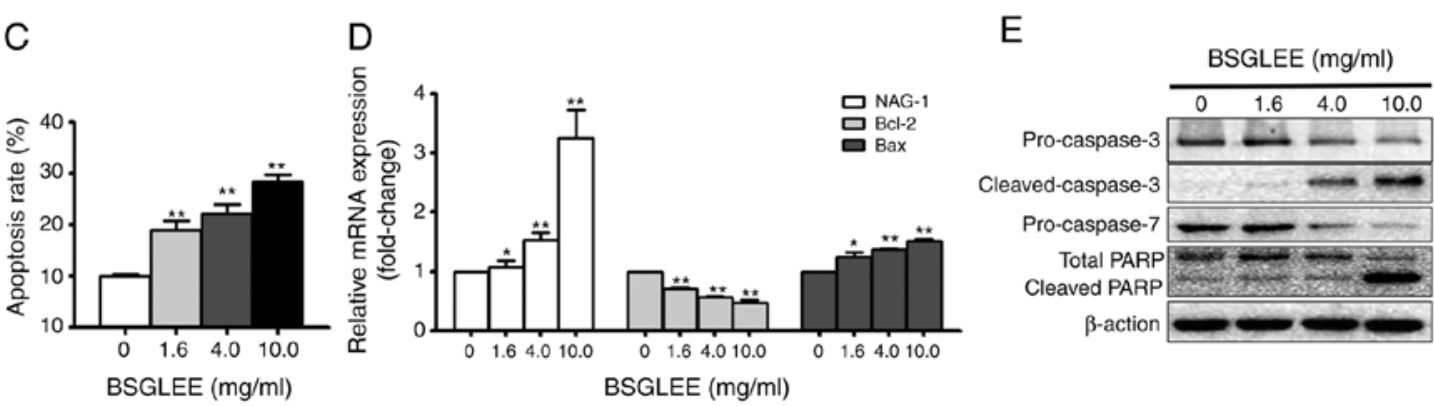

Figure 3. Effect of BSGLEE on cell apoptosis in HCT116 cells. (A) Result from Hoechst 33342 staining. Cells were treated with different concentration of BSGLEE for $36 \mathrm{~h}$. (B) Flow cytometry determination of apoptotic cells after treatment with different concentration of BSGLEE $(0,1.6,4.0 \mathrm{and} 10.0 \mathrm{mg} / \mathrm{ml})$ for $36 \mathrm{~h}$. Figure shows a representative image from three independent experiments. (C) Quantified histograms of the apoptosis ratio of HCT116 cells upon BSGLEE treatment. (D) Quantification of the mRNA levels of apoptosis-related genes after treatment with BSGLEE as determined qRT-PCR. (E) The expression of apoptosis-associated proteins as assessed by western blot analysis. $\beta$-actin was used as an internal control. Statistical data represent mean \pm SD of three independent experiments, ${ }^{*} \mathrm{P}<0.05,{ }^{* *} \mathrm{P}<0.01$.

Fig. 3B, BSGLEE induced a dose-dependent increase in the proportion of early and late apoptotic cells in HCT116 cells at $36 \mathrm{~h}$ of treatment $(\mathrm{P}<0.05$; Fig. 3C). Data presented in Fig. 3B is one representative image out of three experiments. To further explore underlying mechanism of BSGLEE induced apoptosis in HCT116 cells, qRT-PCR and western blot analysis were conducted to examine the key molecules involved in apoptosis cascade. As shown in Fig. 3D, the relative mRNA expression level of $\mathrm{Bcl}-2$ was downregulated $(\mathrm{P}<0.05)$, while the mRNA expression level of Bax was upregulated compared with the untreated cells $(\mathrm{P}<0.05)$. A number of studies have shown that non-steroidal anti-inflammatory drug-activated gene-1 (NAG-1), a pro-apoptotic gene, is upregulated by many anticancer agents and may play an important role in apoptosis induced by these anticancer agents (23). Indeed, we found that the relative mRNA level of NAG-1 was upregulated upon
BSGLEE treatment, especially by the higher concentrations of BSGLEE ( $\mathrm{P}<0.05$; Fig. 3D). Western blot results showed that the expression of pro-caspase- 3 and pro-caspase-7 were reduced upon BSGLEE treatments while cleaved caspase-3 was upregulated, in particular by $10 \mathrm{mg} / \mathrm{ml}$ of BSGLEE, suggesting caspase activation by BSGLEE. In addition, total PARP level was reduced while the cleaved-PARP was upregulated in HCT116 cells upon BSGLEE treatment (Fig. 3E). Taken together, BSGLEE significantly induced apoptosis through de-regulating key genes and proteins that regulate apoptosis cascade in HCT116 cells.

BSGLEE inhibits migration in HCT116 cells. To explore whether the anticancer effect of BSGLEE in vitro is related to cell migration, we examined the motility of HCT116 cells via the scratch wound healing assay. Immediately after cells 
A

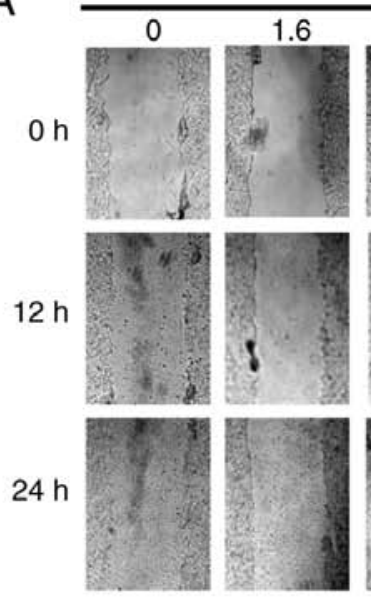

D

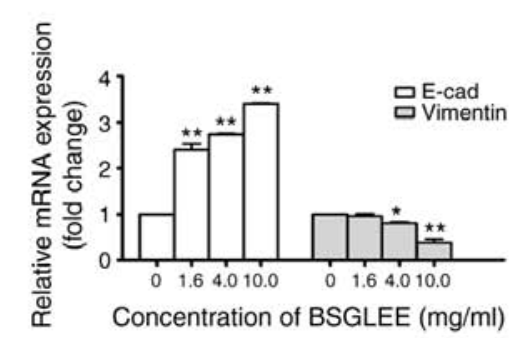

BSGLEE $(\mathrm{mg} / \mathrm{ml})$

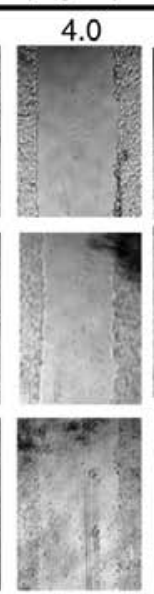

10.0
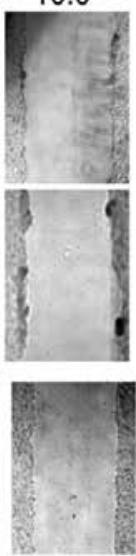

B

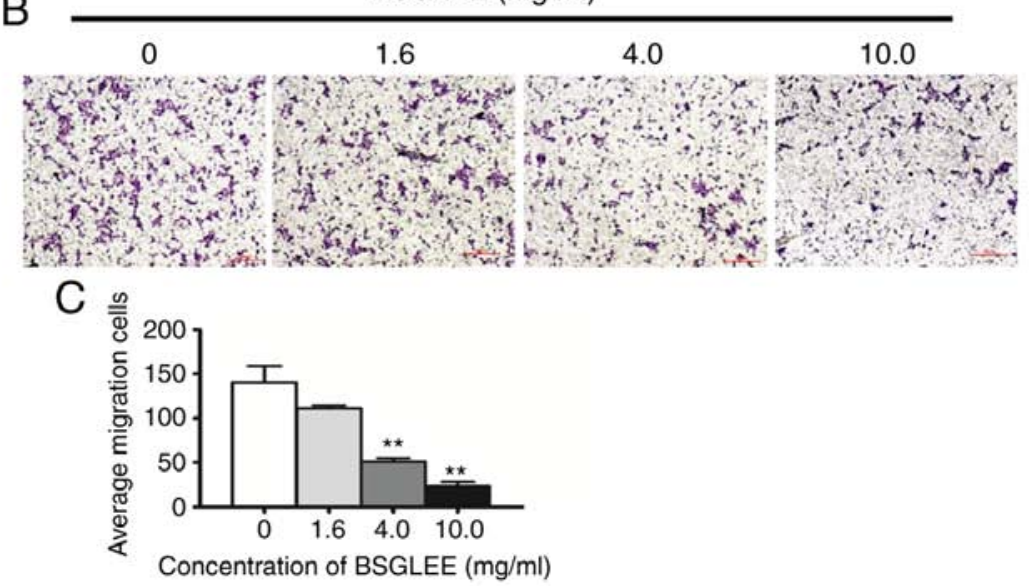

Figure 4. Effect of BSGLEE on cell migration in HCT116 cells. (A) Cell motility upon BSGLEE treatment as determined by wound-healing assay. HCT116 cells were exposed with BSGLEE at 0,1.6, 4.0 and $10.0 \mathrm{mg} / \mathrm{ml}$ for 12 and $24 \mathrm{~h}$, and the pictures were captured by the inverted microscope. (B) BSGLEE inhibited HCT116 cell migration as determined by Transwell experiment. BSGLEE-treated HCT116 cells and untreated HCT116 cells were allowed to migrate in Transwell chambers for $24 \mathrm{~h}$, and the migrated cells were fixed, stained and photographed (magnification, x100). (C) Histogram of the number of migratory cells, which was counted in five chosen areas. (D-F) Quantification of the mRNA levels of migration-related genes after treatment with BSGLEE as determined by qRT-PCR. Data are presented as mean $\pm \mathrm{SD}$ of three independent experiments, ${ }^{*} \mathrm{P}<0.05,{ }^{* *} \mathrm{P}<0.01$.

reached $90 \%$ confluency, the cells were scratched to create wounds. Cells were then treated with a various concentration of BSGLEE (1.6, 4.0 and $10.0 \mathrm{mg} / \mathrm{ml})$ and wound-healing was observed at 12 and $24 \mathrm{~h}$. As depicted in Fig. 4A, treatment with BSGLEE time-dependently delayed cell motility when compared with the controls. In addition, we found that the healing ability of cells was gradually reduced upon BSGLEE treatment in a dose-dependent manner (Fig. 4A). To confirm results from wound healing experiment, we further performed Transwell assay. Compared to control cells, the number of cells treated with BSGLEE that penetrated through the porous membrane (as stained purple) was significantly decreased in a dose-dependent manner (Fig. 4B and C). These data demonstrated that BSGLEE could significantly inhibit HCT116 cell migration in dose-dependent manner. These observations suggest that the migration of HCT116 cells could be inhibited by BSGLEE in a dose- and time-dependent manner. Next, we examined the expression of key genes that are related with cell migration upon BSGLEE treatment in HCT116 cells. As determined by qRT-PCR assay, the relative mRNA expression levels of Fra-1, c-Met and vimentin were downregulated in the HCT116 cells upon BSGLEE treatment, especially at significant level by higher doses (Fig. 4D and E). The relative mRNA expression of MMP-1 and MMP-2, but not MMP-9 (data not shown), was significantly reduced upon BSGLEE treatment with MMP-1 and has a better dose-response $(\mathrm{P}<0.05$; Fig. 4F). Besides, we found the mRNA level of E-cadherin, a tumor suppressor gene that controls cell adhesion, was signifi- cantly upregulated in a dose-dependent manner by BSGLEE $(\mathrm{P}<0.05$; Fig. 4D). However, there was no significant change of the expression upon BSGLEE treatments of Snail, Twist, and Slug which are all cell adhesion and migration regulators in HCT116 cells (data not shown). Taken together, these results suggest that BSGLEE could suppress migration of HCT116 cells through downregulating the expression of MMP-1 and MMP-2 and upregulating E-cadherin.

BSGLEE inhibits xenograft tumor growth in vivo. To evaluate the antitumor effects of BSGLEE on initiation and development of colorectal cancer in vivo, we examined rate of tumor formation, tumor volume and tumor weight in xenograft nude mice upon BSGLEE treatment. As shown in Fig. 5A, rate of tumor formation were dose-dependently delayed by BSGLEE treatments. In the model group, $100 \%(12 / 12)$ of mice developed palpable tumor 14 days after injection of HCT116 cells. In contrast, only $58.3 \%$ (7/12) of mice in $75 \mathrm{mg} / \mathrm{kg}$ and $50 \%$ $(6 / 12)$ of mice in $150 \mathrm{mg} / \mathrm{kg}$ BSGLEE treatment groups developed palpable tumor 14 days after injection (Fig. 5A). In addition, by day $19,75 \mathrm{mg} / \mathrm{kg}$ BSGLEE group reached maximum tumor formation rate as $91.3 \%$ (11/12), while until 25 days after HCT116 injection, $150 \mathrm{mg} / \mathrm{kg}$ group reached maximum tumor formation rate at $83.3 \%$ (10/12) (Fig. 5A). These data indicate that oral gavage of BSGLEE could effectively delay tumor formation in a dose-dependent manner, suggesting a chemopreventive role in colon cancer at early stage. During the experiment, the volume of tumors in each 

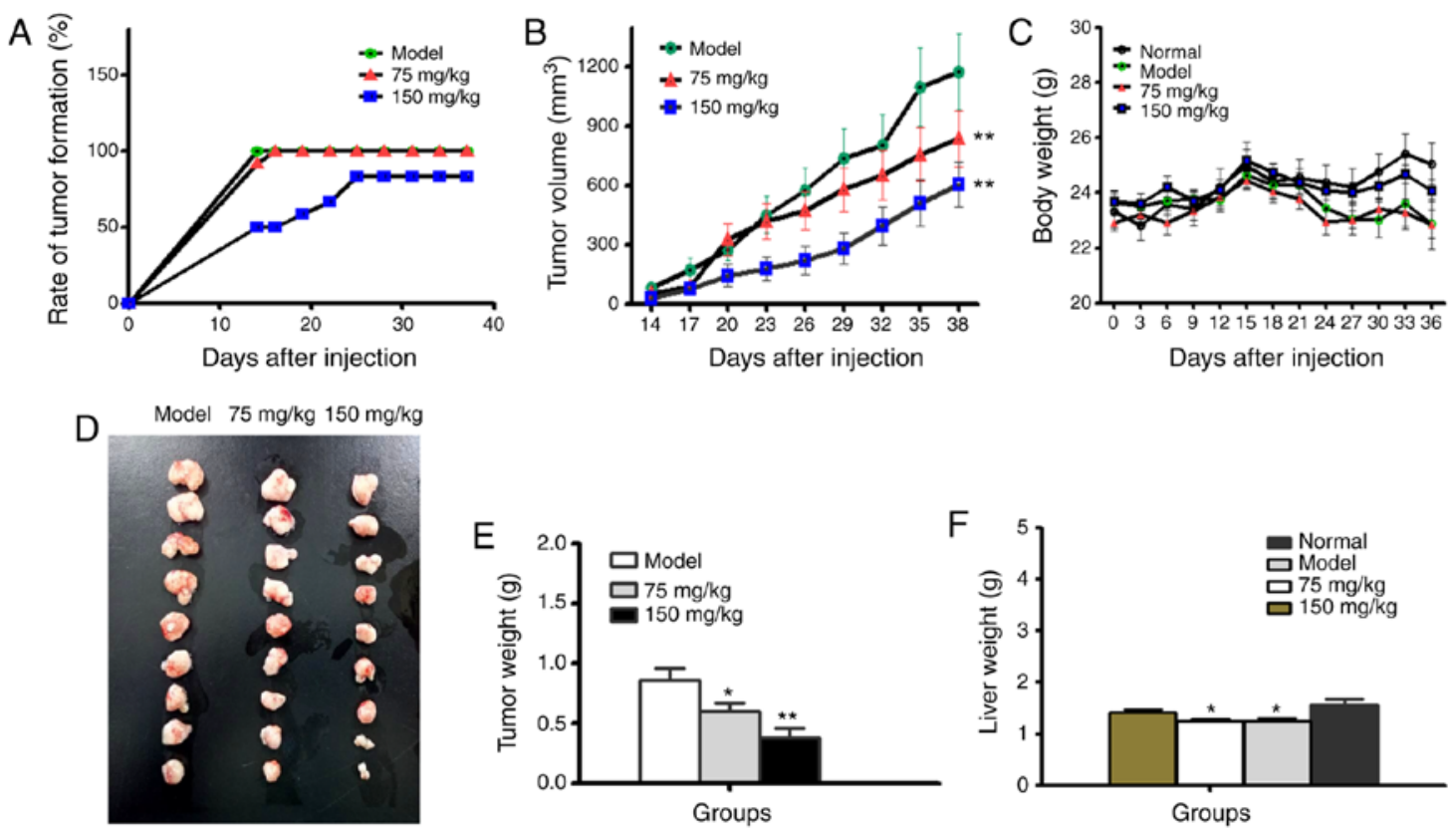

Figure 5. Effects of BSGLEE on HCT116 xenograft tumor growth in nude mice. (A) Tumor formation rate which was calculated as number of mice with tumor/total number of mice in the group. All nude mice were examined daily for tumor formation. (B) Tumor volume ( $\mathrm{mm}^{3}$ ) of nude mouse xenografts as measured twice a week. (C) Body weight (g) change curve in nude mice. (D) Image of the tumor tissues dissected from nude mice and lined according to tumor size in each group at necropsy. (E) Average final tumor weight $(\mathrm{g})$ of nude mice at necropsy. (F) Average liver weight of nude mice from each group. Data are presented as mean $\pm \mathrm{SE}$ of all mice in each group, ${ }^{*} \mathrm{P}<0.05,{ }^{* *} \mathrm{P}<0.01$.

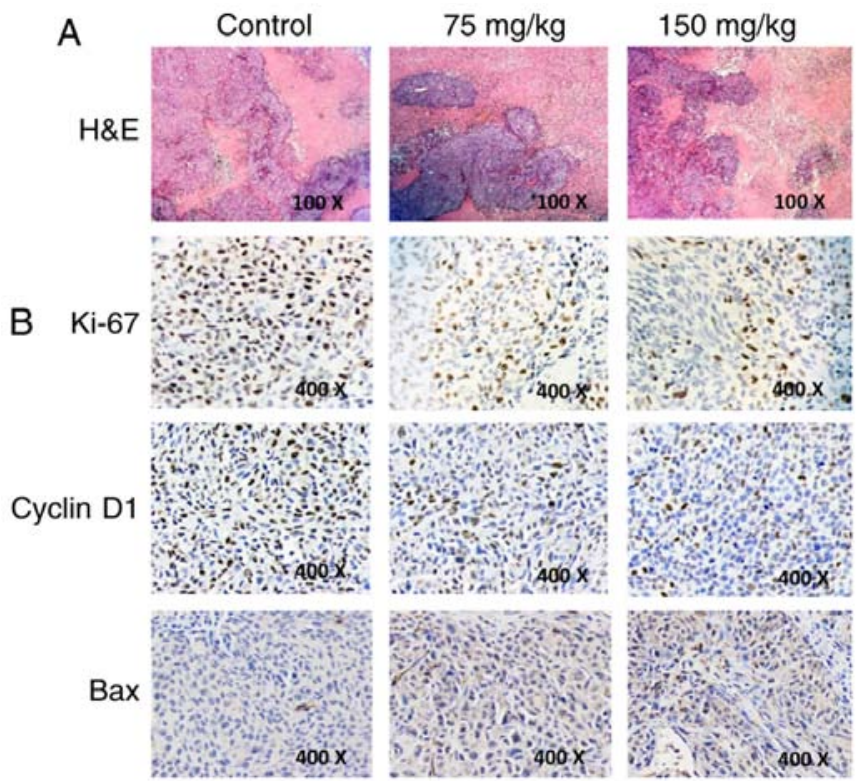

Figure 6. H\&E and immunochemistry staining in HCT116 xenograft tumors upon BSGLEE treatment. (A) H\&E analysis of necrosis (magnification, x100). (B) Expression of Ki-67, cyclin D1 and Bax in xenograft tumors (magnification, $\mathrm{x} 400)$.

group increased continuously (Fig. 5B). However, the tumor volume of BSGLEE treated groups was significantly smaller than that of model group (Fig. 5B). Although the body weights of tumor-bearing mice are all lower than normal group (no HCT116 cell injection), there were no significant differences in body weights among tumor-bearing mice throughout the experiment (Fig. 5C). At the end of the experiment, the body weight of normal group (without HCT116 cell injection), model group, $75 \mathrm{mg} / \mathrm{kg}$ group and $150 \mathrm{mg} / \mathrm{kg}$ group were as follows: $25.06 \pm 1.08,23.34 \pm 2.52,22.84 \pm 1.5$ and $23.14 \pm 2.47 \mathrm{~g}$, respectively (Fig. 5C).

At necropsy, all tumors were carefully excised and displayed according to their sizes as shown in Fig. 5D. It is obvious that tumors in BSGLEE treated groups are much smaller than model group. The mean tumor weights were $0.86 \pm 0.28$, $0.59 \pm 0.20$ and $0.38 \pm 0.23 \mathrm{~g}$ for model group, $75 \mathrm{mg} / \mathrm{kg}$ group and $150 \mathrm{mg} / \mathrm{kg}$ group, respectively $(\mathrm{P}<0.05 ;$ Fig. $5 \mathrm{E})$. In addition, we found the weights of liver tissues of the nude mice in the model and $75 \mathrm{mg} / \mathrm{kg}$ BSGLEE groups were significantly lower than normal group ( $\mathrm{P}<0.05$; Fig. 5F), suggesting xenograft tumor had a negative effect on liver weights. However, $150 \mathrm{mg} / \mathrm{kg}$ of BSGLEE treatment seemed to alleviate this effect which was probably due to smaller tumor burden. Notably, the body weight of nude mice in $150 \mathrm{mg} / \mathrm{kg}$ group seemed also closer to normal group compared to model group and $75 \mathrm{mg} / \mathrm{kg}$ BSGLEE treatment group (Fig. 5C), which may probably also due to smaller tumor sizes in $150 \mathrm{mg} / \mathrm{kg}$ group.

Since necrosis is often induced in tumors upon treatment with anticancer agents, we examined whether BSGLEE treatment could induce more necrosis than model group in xenograft tumors by H\&E staining. However, H\&E staining revealed that BSGLEE did not induce more necrosis in xenograft tumors as characterized by large blurred, massive, unstructured redstained material as compared with dark purple stained living cells in non-necrotic area (Fig. 6A). Besides, we examined the molecular mechanisms through which BSGLEE inhibits tumor growth in HCT116 xenografts by immunochemistry staining. Ki-67 staining of tumor sections was performed to examine whether proliferation was reduced upon BSGLEE treatment. We found that both 75 and $150 \mathrm{mg} / \mathrm{kg}$ of BSGLEE dramatically decreased $\mathrm{Ki}-67$ staining, suggesting a reduction 
of proliferation in tumor samples upon BSGLEE treatments (Fig. 6B). In addition, we found the expression of cell cycle regulator cyclin D1 was dramatically reduced upon BSGLEE treatment, especially by $150 \mathrm{mg} / \mathrm{kg}$ of the ethanol extracts (Fig. 6B). We also performed TUNEL staining to determine whether BSGLEE could induce apoptosis in xenograft tumors. However, TUNEL staining failed to show BSGLEE could induce apoptosis in tumor samples (data not shown), but we did observe an increased intensity of Bax staining in the tumor sections treated with BSGLEE in a dose-dependent manner (Fig. 6B), while we could not detect Bcl-2 expression (data not shown). Taken together, our in vivo study suggests that BSGLEE is effective in inhibiting HCT116 xenograft development and progression through multiple mechanisms in nude mice.

\section{Discussion}

Cancer patients treated by chemotherapy and/or radiotherapy often suffer serious side-effects. The use of traditional Chinese medicine (TCM) in cancer prevention and therapy has received recognition by the West as adjunct/alternative to conventional cancer therapy and prevention (24). An understanding of the molecular basis and highlighting their potential applications for cancer treatment is crucial (24). Among numerous TCM, G. lucidum is one of the most widely studied TCM. G. lucidumis a medicinal mushroom that has been used in East Asian for over 2000 years for promotion of vitality and longevity. At present, a large number of studies have demonstrated that the ethanol extracts of G.lucidum from fruiting bodies or mycelia that mainly contain triterpenoids have a variety of anti-carcinogenesis effects in many types of cancer. Recently, with the advance in sporoderm-breaking technology, ethanol extracts from the sporoderm-broken spores of G. lucidum (BSGL), which contains more triterpenoids $(12,20)$ became a new field of interest for prevention studies. However, the anticancer effects and mechanism by which the BSGL ethanol extract (BSGLEE) exerts on colorectal cancer have not yet been reported. The present study demonstrates that BSGLEE is very potent in inhibiting colorectal cancer HCT116 cell proliferation and xenograft tumor development through inducing cell cycle arrest, inhibiting migration and increasing apoptosis, which are associated with deregulation of key molecules that regulating these pathways.

During the multistep development of human tumors, at least six biological capabilities are acquired by cells undergoing tumorigenesis, which are considered as hallmarks of cancer (25). These hallmarks include sustaining proliferative signaling, evading growth suppressors, resisting cell death, enabling replicative immortality, inducing angiogenesis and activating invasion and metastasis (25). It has been well recognized that the inhibition of proliferation, migration and induction of apoptosis are significant mechanisms through which anticancer agents exert to inhibit carcinogenesis. In this study, we found that BSGLEE significantly suppressed HCT116 cell proliferation in a dose- and time-dependent manner. This inhibitory effect of BSGLEE on colon cancer cells is associated with blocking the cell cycle progression at the G0/G1 phase and induction of apoptosis.
Cell cycle progression is regulated by a complex of celldivision cyclins and cyclin-dependent kinases (CDKs) (26). It has been reported that tumor cells frequently display an upregulated expression of cyclin D1 (27,28), cyclin E (29), CDK1, CDK2 and CDK4 (30,31). p16 and p21 are members of CDK inhibitor (CKI) family which can specifically inhibit activity of cyclins and CDKs and thus delay cell cycle progression. In various tumor cell lines and solid tumors, the expression of CKIs was suppressed (32). Consistent with literature, we found that the mRNA expression of p16 and p21 was upregulated upon BSGLEE treatment in HCT116 cells. In addition, a reduction of cyclin D, cyclin E, CDK1, CDK2 and CDK4 expression at mRNA levels was also observed. These data suggest that anti-proliferative effects of BSGLEE in HCT116 cells may be through inhibiting cell cycle progression. Correlating with our study, Ruan et al (33) reported that a mixture of triterpenoids of G. lucidum induced cell accumulation at G1 phase in HeLa cells. A recent study found $G$. lucidum triterpenoid-induced primarily cell cycle arrest at G1/G0 phase was due to upregulation of p21 expression and the downregulation of CDK4 expression in prostate cancer cells (34). These data suggest that cell cycle arrest is one of the potential mechanisms by which BSGLEE elicits its anti-proliferation activity in colorectal cancer cells.

Apoptosis is an independent cell ordered death process, which is regulated by strict and complex signal network with a series of related genes needing to be coordinated (25). Anticancer agent that can effectively induce apoptosis of cancer cells could serve as a promising candidate for cancer chemoprevention or therapy. In the present study, we found that BSGLEE was effective in inducing apoptosis in HCT116 cells in a dose-dependent manner. Many studies reported that Bcl-2 is highly expressed in colon cancer $(35,36)$ and overexpression of Bax increases apoptosis induced by chemotherapeutic agents (35). The pro-apoptotic gene NAG-1 is a divergent member of the transforming growth factorbeta (TGF- $\beta$ ) family. Shim and Eling reported that NAG-1 expression in VES-treated PC-3 human prostate carcinoma cells was upregulated and NAG-1 plays an important role in VES-induced apoptosis (37). Notably, we also found that the relative mRNA expression level of NAG-1 and Bax in BSGLEE-induced HCT116 cells were upregulated, while Bcl-2 expression is downregulated. In addition, western blot analysis showed that the expression of pro-caspase- 3 and pro-caspase-7 were downregulated, suggesting a caspase activation, which play a pro-apoptotic role in cells. Consistent with our results, Chen et al (38) reported that BSGLEE suppressed the growth of human lung cancer cells through inducing apoptosis, which may be partially regulated through inhibition of the Akt/mTOR signaling pathway. Autophagy, another form of cell death has been shown to play a role in anticancer agents-induced cell death in cancer cells as well. Some scholars reported that triterpenoids from G. lucidum could induce autophagy in colon cancer cells through inhibition of the expression of $\mathrm{p} 38$ mitogen-activated kinase (p38 MAPK) (39). However, whether BSGLEE could induce autophagy in HCT 116 cells need to be examined in future studies.

In addition, we found that BSGLEE inhibited cell migration as determined by wound healing and Transwell assays, and this effect was associated with a significant upregula- 
tion of E-cadherin (E-cad) and downregulation of MMP-1 and MMP-2. E-cadherin, a tumor suppressor gene, plays an important role in the process of cell adhesion, which is downregulated in many tumors (40). MMP-1 is an interstitial collagenase and member of the zinc-dependent endopeptidase family (41). MMP-1 expression is upregulated in many cancers which is associated with poor patient outcome (41). MMP-2 also plays an important role during carcinogenesis. Consistent with our results, Martínez-Montemayor et al (42) reported that G. lucidum whole extract significantly inhibited breast cancer cell invasion through upregulating E-cadherin and downregulating MMP-9. Study by Jang et al (14) found ethanol extracts of G. lucidum induced anti-invasiveness in human gastric cancer AGS cells through inhibiting MMP-2. Taken together, this study suggests that BSGLEE inhibited migration of HCT116 cells mainly through downregulating MMP-1 and MMP-2, and upregulating E-cadherin expression.

To further examine the anti-carcinogenesis effect of BSGLEE in colon cancer, we conducted in vivo study using xenograft nude mice. We found that BSGLEE could significantly inhibit formation and growth of xenograft tumors in nude mice. Treatment with BSGLEE obviously decreased the proliferation and slightly induced apoptosis in xenograft tumors, as evidenced by the Ki-67 and Bax staining assay, which was consistent with our results in vitro. Correlating with our study, a methanol extract from G. lucidum significantly inhibited B16 mouse melanoma growth in vivo (43). Several studies suggest that G. lucidum has a hepatoprotective effect $(7,43,44)$. One study found that the ethanol extract of G. lucidum treatment is effective in protecting against ethanol-induced acute hepatic injury in SD rats by modulating the activities of ethanol-metabolizing enzymes and by attenuating oxidative stress (7). Shi et al (44) found pretreatment of mice with G. lucidum peptides reduced D-galactosamine (D-GalN)-induced hepatic injury, including a significant decrease in the activity of superoxide dismutase (SOD) and in the glutathione (GSH) level in the liver. In this study, we were not able to examine whether $G$. lucidum have the above effects in liver of the nude mice. We did observe an increase of liver tissue weight upon $150 \mathrm{mg} / \mathrm{kg}$ BSGLEE treatment. However, the increase of liver weight by $150 \mathrm{mg} / \mathrm{kg}$ BSGLEE may only be due to less tumor burden in this group. In addition, we found that BSGLEE supplementation did not show any toxicity to the mice. Several clinical studies demonstrated that supplementation with G. lucidum is overall safe in human subjects. For example, a prospective, randomized, double-blind, placebocontrolled study reported that 4 -week intake of $1.5 \mathrm{~g} /$ day G. lucidum did not impair platelet and global hemostatic function and was demonstrated to be safe in healthy volunteers (45). In one double-blind, placebo-controlled, randomized clinical study, Noguchi et al (46) reported that G. lucidum ethanol extract (6 mg once a day) was well tolerated and significantly improved lower urinary tract symptoms in men. Another study found that $G$. lucidum intake for 4 weeks in a controlled human supplementation study shows no toxicity to subjects (47). Although many studies have examined anticancer effects of G. lucidum triterpenoids in laboratory studies, clinical studies are still lacking. Compared to several available studies using water extract of G. lucidum (mainly contains polysaccharides), few or no studies examined health benefits of G. lucidum ethanol extracts in cancer patients. One randomized, doubleblind, placebo-controlled study reported a Chinese medicinal herb complex that contains whole extracts of G. lucidum has significantly improved the immune function of cancer patients receiving chemotherapy and/or radiotherapy (48). However, evidence from well-designed human clinical trials is still scarce. In particular, clinical studies using ethanol extracts of G. lucidum as new nutraceutical or drug for the prevention and treatment of colorectal cancer are needed in future studies.

In conclusion, the present study demonstrated that the ethanol extracts that mainly contain triterpenoids of the sporoderm-broken spores of G. lucidum significantly inhibited colorectal cancer cell proliferation and xenograft tumor growth through deregulating expression of the key molecules of cell cycle, apoptosis and proliferation. To the best of our knowledge, this is the first study to examine the chemopreventive effects of BSGLEE that mainly contains a mixture of triterpenoids in colorectal cancer. Our results also indicate that BSGLEE may serve as a novel anticancer agent for colorectal cancer prevention and therapy.

\section{Acknowledgements}

We thank Yu Huang at the Animal Facility of Zhejiang Medical University for maintenance of the nude mice. The present study was supported by the National Natural Science Foundation of China (grant no. 81473397).

\section{References}

1. Siegel RL, Miller KD and Jemal A: Cancer statistics, 2016. CA Cancer J Clin 66: 7-30, 2016.

2. Bishop KS, Kao CH, Xu Y, Glucina MP, Paterson RR and Ferguson LR: From 2000 years of Ganoderma lucidum to recent developments in nutraceuticals. Phytochemistry 114: 56-65, 2015.

3. Akihisa T, Nakamura Y, Tagata M, Tokuda H, Yasukawa K, Uchiyama E, Suzuki T and Kimura Y: Anti-inflammatory and anti-tumor-promoting effects of triterpene acids and sterols from the fungus Ganoderma lucidum. Chem Biodivers 4: 224-231, 2007.

4. Ko HH, Hung CF, Wang JP and Lin CN: Antiinflammatory triterpenoids and steroids from Ganoderma lucidum and G. tsugae. Phytochemistry 69: 234-239, 2008.

5. Hu H, Ahn NS, Yang X, Lee YS and Kang KS: Ganoderma lucidum extract induces cell cycle arrest and apoptosis in MCF-7 human breast cancer cell. Int J Cancer 102: 250-253, 2002.

6. Wu G, Qian Z, Guo J, Hu D, Bao J, Xie J, Xu W, Lu J, Chen X and Wang Y: Ganoderma lucidum extract induces G1 cell cycle arrest, and apoptosis in human breast cancer cells. Am J Chin Med 40: 631-642, 2012.

7. Jang SH, Cho SW, Yoon HM, Jang KJ, Song CH and Kim CH: Hepatoprotective evaluation of Ganoderma lucidum pharmacopuncture: In vivo studies of ethanol-induced acute liver injury. $\mathrm{J}$ Pharmacopuncture 17: 16-24, 2014.

8. Mowsumi FR, Rahman MM, Rahaman A, Selina FA, Islam MJ and Bhuiyan MHS: Preventive effect of Ganoderma lucidum on paraetamol-induced acute hepatotoxicity in rats. Bangladesh J Sci Res 5: 573-578, 2013.

9. Lam FF, Ko IW, Ng ES, Tam LS, Leung PC and Li EK: Analgesic and anti-arthritic effects of Lingzhi and San Miao San supplementation in a rat model of arthritis induced by Freund's complete adjuvant. J Ethnopharmacol 120: 44-50, 2008.

10. Koyama K, Imaizumi T, Akiba M, Kinoshita K, Takahashi K, Suzuki A, Yano S, Horie S, Watanabe K and Naoi Y: Antinociceptive components of Ganoderma lucidum. Planta Med 63: 224-227, 1997.

11. el-Mekkawy S, Meselhy MR, Nakamura N, Tezuka Y, Hattori M, Kakiuchi N, Shimotohno K, Kawahata T and Otake T: AntiHIV-1 and anti-HIV-1-protease substances from Ganoderma lucidum. Phytochemistry 49: 1651-1657, 1998. 
12. Wu GS, Guo JJ, Bao JL, Li XW, Chen XP, Lu JJ and Wang YT: Anti-cancer properties of triterpenoids isolated from Ganoderma lucidum - a review. Expert Opin Investig Drugs 22: 981-992, 2013.

13. Boh B, Berovic M, Zhang J and Zhi-Bin L: Ganoderma lucidum and its pharmaceutically active compounds. Biotechnol Annu Rev 13: 265-301, 2007.

14. Jang KJ, Son IS, Shin DY, Yoon HM and Choi YH: Anti-invasive activity of ethanol extracts of Ganoderma lucidum through tightening of tight junctions and inhibition of matrix metalloproteinase activities in human gastric carcinoma cells. J Acupunct Meridian Stud 4: 225-235, 2011.

15. Jang KJ, Han MH, Lee BH, Kim BW, Kim CH, Yoon HM and Choi YH: Induction of apoptosis by ethanol extracts of Ganoderma lucidum in human gastric carcinoma cells. J Acupunct Meridian Stud 3: 24-31, 2010.

16. Yuen JW, Gohel MD and Au DW: Telomerase-associated apoptotic events by mushroom Ganoderma lucidum on premalignant human urothelial cells. Nutr Cancer 60: 109-119, 2008.

17. Zhu HS, Yang XL, Wang LB, Zhao DX and Chen L: Effects of extracts from sporoderm-broken spores of Ganoderma lucidum on HeLa cells. Cell Biol Toxicol 16: 201-206, 2000.

18. Hong KJ, Dunn DM, Shen CL and Pence BC: Effects of Ganoderma lucidum on apoptotic and anti-inflammatory function in HT-29 human colonic carcinoma cells. Phytother Res 18: 768-770, 2004.

19. Lin SB, Li CH, Lee SS and Kan LS: Triterpene-enriched extracts from Ganoderma lucidum inhibit growth of hepatoma cells via suppressing protein kinase $\mathrm{C}$, activating mitogen-activated protein kinases and G2-phase cell cycle arrest. Life Sci 72: 2381-2390, 2003.

20. Min BS, Nakamura N, Miyashiro H, Bae KW and Hattori M: Triterpenes from the spores of Ganoderma lucidum and their inhibitory activity against HIV-1 protease. Chem Pharm Bull (Tokyo) 46: 1607-1612, 1998

21. Lu QY, Jin YS, Zhang Q, Zhang Z, Heber D, Go VL, Li FP and Rao JY: Ganoderma lucidum extracts inhibit growth and induce actin polymerization in bladder cancer cells in vitro. Cancer Lett 216: 9-20, 2004

22. Wynne S and Djakiew D: NSAID inhibition of prostate cancer cell migration is mediated by Nag-1 induction via the p38 MAPK-p75(NTR) pathway. Mol Cancer Res 8: 1656-1664, 2010.

23. Wang X, Baek SJ and Eling TE: The diverse roles of nonsteroidal anti-inflammatory drug activated gene (NAG-1/GDF15) in cancer. Biochem Pharmacol 85: 597-606, 2013.

24. Parekh HS, Liu G and Wei MQ: A new dawn for the use of traditional Chinese medicine in cancer therapy. Mol Cancer 8 : 21, 2009. https://doi.org/10.1201/b16611-11.

25. Hanahan D and Weinberg RA: The hallmarks of cancer. Cell 100: 57-70, 2000.

26. Lim S and Kaldis P: Cdks, cyclins and CKIs: Roles beyond cell cycle regulation. Development 140: 3079-3093, 2013.

27. Alao JP: The regulation of cyclin D1 degradation: Roles in cancer development and the potential for therapeutic invention. Mol Cancer 6: 24, 2007.

28. Liu Y, Bi T, Wang Z, Wu G, Qian L, Gao Q and Shen G: Oxymatrine synergistically enhances antitumor activity of oxaliplatin in colon carcinoma through $\mathrm{PI} 3 \mathrm{~K} / \mathrm{AKT} / \mathrm{mTOR}$ pathway. Apoptosis 21: 1398-1407, 2016.

29. Gong J, Ardelt B, Traganos F and Darzynkiewicz Z: Unscheduled expression of cyclin B1 and cyclin E in several leukemic and solid tumor cell lines. Cancer Res 54: 4285-4288, 1994.

30. Cho HJ and Park JH: Kaempferol induces cell cycle arrest in HT-29 human colon cancer cells. J Cancer Prev 18: 257-263, 2013.

31. Lee DE, Lee KW, Jung SK, Lee EJ, Hwang JA, Lim TG, Kim BY, Bode AM, Lee HJ and Dong Z: 6,7,4'-trihydroxyisoflavone inhibits HCT-116 human colon cancer cell proliferation by targeting CDK1 and CDK2. Carcinogenesis 32: 629-635, 2011.

32. Graña X and Reddy EP: Cell cycle control in mammalian cells: Role of cyclins, cyclin dependent kinases (CDKs), growth suppressor genes and cyclin-dependent kinase inhibitors (CKIs). Oncogene 11: 211-219, 1995.
33. Ruan W, Wei Y and Popovich DG: Distinct responses of cytotoxic Ganoderma lucidum triterpenoids in human carcinoma cells. Phytother Res 29: 1744-1752, 2015.

34. Wang T, Xie ZP, Huang ZS, Li H, Wei AY, Di JM, Xiao HJ, Zhang ZG, Cai LH, Tao X, et al: Total triterpenoids from Ganoderma Lucidum suppresses prostate cancer cell growth by inducing growth arrest and apoptosis. J Huazhong Univ Sci Technolog Med Sci 35: 736-741, 2015.

35. Kobayashi T, Sawa H, Morikawa J, Zhang W and Shiku H: Bax induction activates apoptotic cascade via mitochondrial cytochrome c release and Bax overexpression enhances apoptosis induced by chemotherapeutic agents in DLD-1 colon cancer cells. Jpn J Cancer Res 91: 1264-1268, 2000.

36. Paul-Samojedny M1, Kokocińska D, Samojedny A, Mazurek U, Partyka R, Lorenz Z and Wilczok T: Expression of cell survival/ death genes: $\mathrm{Bcl}-2$ and $\mathrm{Bax}$ at the rate of colon cancer prognosis. Biochim Biophys Acta 25-29: 2005.

37. Shim $M$ and Eling TE: Vitamin E succinate induces NAG-1 expression in a p38 kinase-dependent mechanism. Mol Cancer Ther 7: 961-971,2008.

38. Chen Y, Lv J, Li K, Xu J, Li M, Zhang W and Pang X: Sporodermbroken spores of Ganoderma lucidum inhibit the growth of lung cancer: Involvement of the Akt/mTOR signaling pathway. Nutr Cancer 68: 1151-1160, 2016

39. Thyagarajan A, Jedinak A, Nguyen H, Terry C, Baldridge LA, Jiang J and Sliva D: Triterpenes from Ganoderma Lucidum induce autophagy in colon cancer through the inhibition of p38 mitogen-activated kinase (p38 MAPK). Nutr Cancer 62: 630-640, 2010

40. Castro Alves C, Rosivatz E, Schott C, Hollweck R, Becker I, Sarbia M, Carneiro F and Becker KF: Slug is overexpressed in gastric carcinomas and may act synergistically with SIP1 and Snail in the down-regulation of E-cadherin. J Pathol 211: 507-515, 2007.

41. Shin DH, Dier U, Melendez JA and Hempel N: Regulation of MMP-1 expression in response to hypoxia is dependent on the intracellular redox status of metastatic bladder cancer cells. Biochim Biophys Acta 1852: 2593-2602, 2015.

42. Martínez-Montemayor MM, Acevedo RR, Otero-Franqui E, Cubano LA and Dharmawardhane SF: Ganoderma lucidum (Reishi) inhibits cancer cell growth and expression of key molecules in inflammatory breast cancer. Nutr Cancer 63: 1085-1094, 2011.

43. Liu LY, Chen H, Liu C, Wang HQ, Kang J, Li Y and Chen RY: Triterpenoids of Ganoderma theaecolum and their hepatoprotective activities. Fitoterapia 98: 254-259, 2014.

44. Shi Y, Sun J, He H, Guo H and Zhang S: Hepatoprotective effects of Ganoderma lucidum peptides against D-galactosamineinduced liver injury in mice. J Ethnopharmacol 117: 415-419, 2008.

45. Kwok Y, Ng KF, Li CC, Lam CC and Man RY: A prospective, randomized, double-blind, placebo-controlled study of the platelet and global hemostatic effects of Ganoderma lucidum (Ling-Zhi) in healthy volunteers. Anesth Analg 101: 423-426, table of contents, 2005.

46. Noguchi M, Kakuma T, Tomiyasu K, Yamada A, Itoh K, Konishi F, Kumamoto S, Shimizu K, Kondo R and Matsuoka K: Randomized clinical trial of an ethanol extract of Ganoderma lucidum in men with lower urinary tract symptoms. Asian J Androl 10: 777-785, 2008.

47. Wachtel-Galor S, Szeto YT, Tomlinson B and Benzie IF: Ganoderma lucidum ('Lingzhi'); acute and short-term biomarker response to supplementation. Int J Food Sci Nutr 55: 75-83, 2004.

48. Zhuang SR, Chen SL, Tsai JH, Huang CC, Wu TC, Liu WS Tseng HC, Lee HS, Huang MC, Shane GT, et al: Effect of citronellol and the Chinese medical herb complex on cellular immunity of cancer patients receiving chemotherapy/radiotherapy. Phytother Res 23: 785-790, 2009. 